\title{
Miscellany
}

\section{Locum doctors required for South Australia}

There are multiple vacancies for psychiatric RMOs and SHOs in South Australia; subsidised air fares and accommodation will be provided. Doctors able to work in South Australia at any time between now and February 1991 are asked to ring David Penny, Adelaide 082311311 (reverse charge).

\section{Delegation from the Hungarian Psychiatric Association}

The Hungarian Psychiatric Association is sending a delegation to the Autumn Quarterly Meeting 1991 of the College to be held in London on Wednesday 23 and Thursday 24 October 1991. Affordable accommodation for non-speaking delegates is very difficult to find in London. The Hungarian psychiatrists were very generous hosts to our Study Tour there last year. Would any members of the College able to offer hospitality to a member of the delegation contact Deborah Hart at the College.

Dr CoRnelius Katona Secretary Programmes and Meetings Committee

\section{The Merck, Sharp and Dohme Prize in Psychiatry}

The winner of the 1990 Merck, Sharp and Dohme Prize in Psychiatry (East Anglia) was Dr Gillian Rose, Registrar at Fulbourn Hospital, Cambridge with an entry on 'Violence and Aggression in Psychiatric Settings: A Review of the Literature'.

The Academic Department of Psychiatry announces that the competition has now been opened for the 1991 MSD Prize; First Prize £250, and Second Prize $£ 80$. Psychiatric trainees working in the East Anglian Region are eligible. Further details: Ms Mary Coburn, PGME Administrator, Fulbourn Hospital, Cambridge (telephone 0223 281673).

\section{Netley Military Asylum}

Mr P. W. Kirkby, Historical Researcher, Netley, is carrying out research on Netley Military Asylum which was built in 1866-80 and used by the Army and Navy as their main psychiatric facility until 1978. The main building is now used by Hampshire Police as their Training Centre and Mr Kirkby is doing the research on their behalf. If any readers served at Netley or have any photographs, documents or other items they may be prepared to lend for copying, he would be pleased to hear from them: P. W. Kirkby, Historical Researcher, Netley, 7 Sutton Gardens, St Peter's Street, Winchester SO23 8HP.

\section{New Publications}

The Prison Medical Service in England and Wales: Recruitment and Training of Doctors (a report of a working party of the Royal College of Physicians to the Chief Medical Officer, March 1989) is available from the Home Office and Department of Health, price $£ 3.20$.

The Forgotten People by Joy Ann McCalman is a new King's Fund Centre report which highlights the isolation of black and ethnic minority carers looking after elderly relatives. It is available from: Bailey Distribution Ltd, Department D/KFP, Warner House, Folkestone, Kent CT19 6PH, price $£ 4.95$, including postage and packing. Cheques should be made payable to Bailey Distribution Ltd.

\section{New charity}

CARE, a new community resource, was launched in September 1990 to provide specialist counselling for those suffering from illness or disability and for members of their families. Founded by Virginia Routh, psychotherapist at Ashford Hospital, and Charles Day, a former parish priest, it offers a wide choice of therapies. It is a non-profit-making registered charity and will charge clients only enough to cover expenses. An initial grant of $£ 7,000$ by King Edward's Hospital Fund for London provided the launching finance. Further information: Virginia Routh or Charles Day, CARE, Arlington Park House, Sutton Lane, Chiswick, London W4 4HD (telephone 081994 0578).

\section{Helping problem drinkers}

The Scottish Health Education Group has launched a new project designed to train GPs in the skills they need to help problem drinkers and to provide them with self-help resources for these patients. Details of the DRAMS scheme (Drinking Reasonably and Moderately with Self-Control) are obtainable from: Yvonne Bostock, The Scottish Health Education Group, Health Education Centre, Woodburn House, Canaan Lane, Edinburgh EH10 4SG (telephone 031447 8044; fax 031452 8140).

\section{Correction}

Dr W. A. Norris, Consultant Psychiatrist, Purdysburn Hospital, Belfast, was awarded the OBE in The Queen's Birthday Honours List and not the MBE as stated in the Psychiatric Bulletin, August 1990, 14, 510. We apologise to Dr Norris for this error. 